\title{
Risk of latent tuberculosis in at-risk children with rheumatic diseases
}

\author{
SC Lim", JE Munro ${ }^{1}$, RC Allen ${ }^{1}$, N Curtis ${ }^{2,3}, J D$ Akikusa ${ }^{1}$ \\ From 18th Pediatric Rheumatology European Society (PReS) Congress \\ Bruges, Belgium. 14-18 September 2011
}

\section{Background}

The risk of developing latent TB infection (LTBI) following exposure to active tuberculosis (TB) in children with rheumatic diseases on immunosuppressive therapy is not well established.

\section{Aim}

To determine the risk of developing LTBI in children with rheumatic diseases following inadvertent exposure to active TB in the course of their clinical care.

\section{Methods}

Data from TB screening by tuberculin skin test (TST) and interferon gamma release assay (Quantiferon TB Gold In tube, (IGRA)) involving at-risk children with rheumatic disease was reviewed. Exposed patients were considered to be at moderate risk of LTBI if they were under 5 years of age, or receiving conventional DMARDs or corticosteroids $>0.5 \mathrm{mg} / \mathrm{kg} /$ day, and at high risk if they were receiving biologic DMARDS. High risk patients also had chest X-rays.

\section{Results}

Results from 55 children were analyzed; 13 (23.6\%) in the high risk category and $42(76.4 \%)$ in the moderate risk category. The duration of exposure to the index case ranged from 30 to 120 minutes. Two children in the high risk group on Etanercept tested positive for TST (negative IGRA). All patients tested negative for IGRA. A positive test result did not correlate with the degree of immunosuppression or cumulative exposure. No patients had symptoms or signs suggestive of active $\mathrm{TB}$ and all chest radiographs were normal.

\footnotetext{
* Correspondence: sernchin@gmail.com

'Rheumatology Unit, Royal Children's Hospital, Melbourne, Australia
}

Full list of author information is available at the end of the article

\section{Conclusion}

The risk of testing positive for LTBI was low in this cohort of children, even in those on potent immunosuppressants. The sensitivity of TST and IGRA in this situation remains unknown.

\section{Author details}

${ }^{1}$ Rheumatology Unit, Royal Children's Hospital, Melbourne, Australia. ${ }^{2}$ Infectious Diseases Unit, Department of General Medicine, Royal Children's Hospital, Melbourne, Australia. ${ }^{3}$ Department of Paediatrics, University of Melbourne, Australia.

Published: 14 September 2011

doi:10.1186/1546-0096-9-S1-P218

Cite this article as: Lim et al:: Risk of latent tuberculosis in at-risk

children with rheumatic diseases. Pediatric Rheumatology 2011 9(Suppl 1): P218.
Submit your next manuscript to BioMed Central and take full advantage of:

- Convenient online submission

- Thorough peer review

- No space constraints or color figure charges

- Immediate publication on acceptance

- Inclusion in PubMed, CAS, Scopus and Google Scholar

- Research which is freely available for redistribution

\section{() Biomed Central}

